\title{
Arthrobacter gandavensis sp. nov., for strains of veterinary origin
}

Correspondence

Virginie Storms

Virginie.Storms@ugent.be

\author{
Virginie Storms, ${ }^{1}$ Luc A. Devriese, ${ }^{2}$ Renata Coopman, ${ }^{1}$ Peter Schumann, ${ }^{3}$ \\ Frank Vyncke ${ }^{1}$ and Monique Gillis ${ }^{1}$
}

'Laboratory of Microbiology, Department of Biochemistry, Physiology and Microbiology, Faculty of Sciences, University of Ghent, K. L. Ledeganckstraat 35, 9000 Gent, Belgium

${ }^{2}$ Department of Pathology, Bacteriology and Poultry Diseases, Faculty of Veterinary Medicine, University of Ghent, Salisburylaan 133, 9820 Merelbeke, Belgium

${ }^{3}$ DSMZ - German Collection of Microorganisms and Cell Cultures, Mascheroder Weg 1b, 38140 Braunschweig, Germany

\begin{abstract}
Three strains of a previously undescribed, Gram-positive, coryneform bacterium, which were isolated from cattle, were subjected to polyphasic taxonomic analysis. Comparative 16S rRNA gene sequencing revealed that the unknown isolates were members of the genus Arthrobacter and were phylogenetically closely related to Arthrobacter luteolus. However, DNA-DNA hybridization indicated that the strains belonged to a new sub-lineage within the genus Arthrobacter. The unknown isolates can be distinguished from related species by biochemical tests. It is proposed that the Arthrobacter-like bacteria of veterinary origin should be classified in the genus Arthrobacter as Arthrobacter gandavensis sp. nov., with the type strain LMG $21285^{\top}$ (=DSM $15046^{\top}$ ).
\end{abstract}

Conn (1928) described a group of bacteria that appeared as Gram-negative rods in young cultures and as Grampositive cocci in older cultures. 'Bacterium globiforme' was proposed for these bacteria; this species, as Arthrobacter globiformis, was later to become the type species of the genus Arthrobacter (Skerman et al., 1980; Jones \& Keddie, 1992). Members of the genus Arthrobacter are distributed widely in the environment, especially in soil, and until recently had not been isolated from clinical sources. Funke et al. (1996) first reported on Arthrobacter strains isolated from clinical specimens, leading to the description of Arthrobacter cumminsii and Arthrobacter woluwensis. In 1998, Arthrobacter creatinolyticus (Hou et al., 1998) was described for strains isolated from human urine. Wauters et al. (2000) found that strains of Arthrobacter oxydans were present in human blood cultures. Their study also led to the description of two novel species of human origin, Arthrobacter luteolus and Arthrobacter albus. Arthrobacter rhombi (Osorio et al., 1999), isolated from fish, and Arthrobacter nasiphocae (Collins et al., 2002), isolated from seals, are thus far the only described Arthrobacter species that originated from animals.

In this article, we report the characteristics of an unknown Arthrobacter species that was isolated from cattle. Strains LMG $21285^{\mathrm{T}}$ and LMG 21287 were isolated from mastitic

The GenBank/EMBL/DDBJ accession numbers for the 16S rRNA gene sequences of strains LMG $21285^{\top}$, LMG 21286 and LMG 21287 are AJ316140, AJ491107 and AJ491108, respectively. milk of dairy cows and strain LMG 21286 was recovered from the uterus of a cow. The three strains were isolated from different animals from separate farms. Based on phenotypic and phylogenetic evidence, Arthrobacter gandavensis sp. nov., is proposed.

Strains were cultured on Columbia agar (BBL; Becton Dickinson) supplemented with $5 \%$ defibrillated sheep blood at $37^{\circ} \mathrm{C}$ in air. Growth in brain heart infusion (BHI) broth and in $\mathrm{BHI}$ broth with $6.5 \% \mathrm{NaCl}$ was tested; cultures were incubated at $37^{\circ} \mathrm{C}$ in air. Enzymic and carbohydrate acidification tests were carried out with API Coryne and API $50 \mathrm{CH}$ kits (bioMérieux) and BBL Crystal Gram-positive ID kits (Becton Dickinson).

Amino acid composition of the peptidoglycan and the major menaquinones for strain LMG $21285^{\mathrm{T}}$ were studied by P. Schumann at DSMZ, following the methods described by Groth et al. (1996).

Cellular fatty acid methyl esters were prepared, separated and identified by using the Microbial Identification system (Microbial ID) as described by Vandamme et al. (1992).

$16 S$ rRNA genes were amplified by PCR and sequenced directly by using a BigDye Terminator Cycle Sequencing Ready Reaction kit and an automatic ABI Prism 310 Genetic Analyser (both from Applied Biosystems). The closest relatives of the new isolates were determined by performing database searches. A phylogenetic tree was constructed with the BioNumerics software package (Applied Maths), based 
on the neighbour-joining method (Saitou \& Nei, 1987), and the stability of groupings was estimated by bootstrap analysis.

For determination of DNA base composition, DNA was degraded enzymically into nucleosides as described by Mesbah et al. (1989). The nucleoside mixture was then separated by HPLC, using a Waters SymmetryShield C8 column that was thermostatted at $37^{\circ} \mathrm{C}$. The solvent was $0.02 \mathrm{M} \mathrm{NH}_{4} \mathrm{H}_{2} \mathrm{PO}_{4}$ (pH 4.0) with $1.5 \%$ acetonitrile. Non-methylated $\lambda$-phage DNA (Sigma) was used as the calibration reference. DNA-DNA hybridization was performed with photobiotin-labelled probes in microplate wells as described by Ezaki et al. (1989) and Goris et al. (1998), using an HTS 7000 BioAssay Reader (Applied Biosystems) for fluorescence measurements. Hybridization temperature was $45^{\circ} \mathrm{C}$ (calculated as optimal renaturation temperature in $2 \times$ SSC and $50 \%$ formamide). DNA was prepared by using a modification of the method of Pitcher et al. (1989).

The three isolates were relatively small $(0 \cdot 5-1 \mu \mathrm{m})$ coccobacilli, often with one pointed end, which resembled cells of members of the genus Arcanobacterium. They grew equally well at 25,30 and $37^{\circ} \mathrm{C}$, but grew less well at $42^{\circ} \mathrm{C}$. No growth was seen when cultured anaerobically and growth was not enhanced by $5 \% \mathrm{CO}_{2}$. The isolates produced yellow-pigmented, smooth, glistening, circular colonies up to $1 \mathrm{~mm}$ in diameter. They were motile, sedimented partially in broth and did not grow in broth that contained $6.5 \% \mathrm{NaCl}$. Strains were catalase-positive and non-fermentative, but produced acid weakly from fructose and ribose when grown aerobically. Strain LMG 21287 also showed a weak reaction with ribose and aesculin. Strain LMG $21285^{\mathrm{T}}$ was D-glucose-negative and was weakly positive for mannose and rhamnose. The three strains reacted in tests for nitrate reduction, pyrazinamidase, $\beta$-galactosidase, $\alpha$-glucosidase, urease (one strain only weakly) and enzymic hydrolysis of L-phenylalanine-AMC, $4 \mathrm{MU}-\beta$-D-glucoside, arginine, $p$-nitrophenyl $\beta$-D-glucoside, leucine- and proline- $p$-nitroanilide, $p$-nitrophenyl phosphate and 4MU-phosphate. Strains LMG 21287 and LMG $21285^{\mathrm{T}}$ liquefied gelatin. Growth at $37^{\circ} \mathrm{C}$ distinguishes $A$. citreus from A. luteolus and A. gandavensis.

Cellular fatty acid analysis revealed that a predominant amount of anteiso- $\mathrm{C}_{15: 0}$ and significant amounts of iso$\mathrm{C}_{15: 0}$ and anteiso- $\mathrm{C}_{17: 0}$ were present, as is the case for A. luteolus (Wauters et al., 2000).

Strain LMG $21285^{\mathrm{T}}$ possesses peptidoglycan of the type A3 $\alpha$ (L-Lys-L-Thr-L-Ala-L-Ala), which supports its assignment to the A. globiformis/A. citreus group (Jones \& Keddie, 1992). The major menaquinone is MK- $9\left(\mathrm{H}_{2}\right)$.

Table 1 contains phenotypic characteristics that are useful for differentiation from the related species A. luteolus and A. citreus, to which the novel species was otherwise very similar phenotypically, notably in its production of bright yellow pigment (Wauters et al., 2000).
Table 1. Characteristics that differentiate $A$. gandavensis from its nearest phylogenetic relatives

Taxa: 1, A. gandavensis; 2, A. luteolus DSM $13067^{\mathrm{T}}$; 3, A. citreus LMG $16338^{\mathrm{T}}$.

\begin{tabular}{|lccc|}
\hline Characteristic & $\mathbf{1}$ & $\mathbf{2}$ & $\mathbf{3}$ \\
\hline$\beta$-Galactosidase & + & - & + \\
Urease & + & - & - \\
Hydrolysis of: & & & \\
$\quad$ Aesculin & + & - & - \\
L-Isoleucine-AMC & - & + & + \\
$p$-Nitrophenyl phosphate & + & - & - \\
$p$-Nitrophenyl $\beta$-D-glucoside & + & - & - \\
Proline- and leucine- $p$-nitroanilide & + & - & - \\
$p$-Nitrophenyl phosphate & + & - & - \\
ONPG and $p$-nitrophenyl $\alpha$-D-galactoside & + & - & - \\
& & & \\
\hline
\end{tabular}

Almost-complete $16 \mathrm{~S}$ rRNA gene sequences of the three isolates were determined and revealed $100 \%$ similarity between LMG $21285^{\mathrm{T}}$ and LMG 21287 and $99.9 \%$ similarity between these strains and LMG 21286 (corresponding to a single base difference), showing their high phylogenetic relatedness. A tree showing the phylogenetic affinity of the new isolates to other members of the genus Arthrobacter is shown in Fig. 1 and reveals that the unknown bacterial species was most closely related to A. luteolus and A. citreus (98.6 and $97 \cdot 2 \%$ similarity by pairwise comparison, respectively). These clustered together with a bootstrap resampling value of $99 \%$ (1000 tree replications).

DNA-DNA hybridizations were performed between the three strains and also with their closest relatives, A. citreus and A. luteolus. Hybridization values are given in Table 2; they show clearly that the three unknown strains belong to the same novel species within the genus Arthrobacter. The DNA G $+C$ content of these three isolates is $65 \mathrm{~mol} \%$.

\section{Description of Arthrobacter gandavensis sp. nov.}

Arthrobacter gandavensis (gan.da.ven'sis. M.L. masc. adj. gandavensis of Gandavum, the Latin name for Ghent, referring to the place where these strains were first isolated).

Cells are Gram-positive, relatively small coccobacilli with one pointed end. They are catalase-positive. Bright yellow pigment is produced. Growth at 25 and $37^{\circ} \mathrm{C}$ is about equal; growth is less abundant at $42{ }^{\circ} \mathrm{C}$. Obligately aerobic. Cells precipitate partially in $\mathrm{BHI}$ broth; unable to grow in $6.5 \%$ $\mathrm{NaCl}$. Acid is produced weakly from aesculin, D-fructose and ribose. No acid is produced from adonitol, amygdalin, D- or L-arabinose, D- or L-arabitol, arbutin, cellobiose, dulcitol, erythritol, D- or L-fucose, galactose, $\beta$-gentiobiose, gluconate, glycogen, glycerol, inositol, inulin, 2- or 5-ketogluconate, lactose, D-lyxose, maltose, maltotriose, mannitol, melezitose, melibiose, methyl $\beta$-glycoside, methyl $\alpha$-D-mannoside, methyl $\alpha$-D-glucoside, D-raffinose, sucrose, 


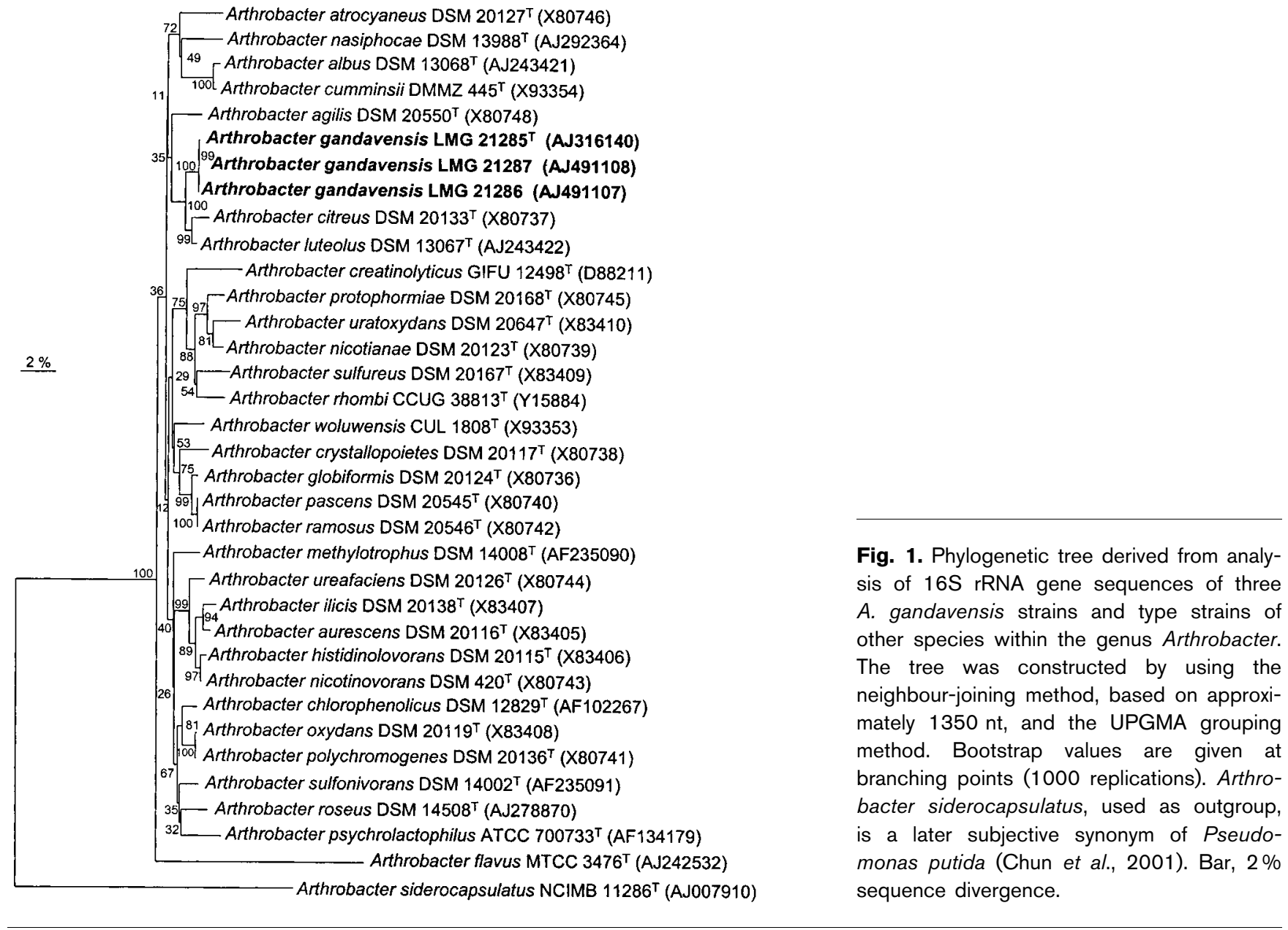

Table 2. DNA-DNA hybridization values and DNA G+C content (mol\%)

\begin{tabular}{|lcrrrrl|}
\hline Species & \multirow{2}{*}{$\begin{array}{c}\text { G+C } \\
\text { content }\end{array}$} & \multicolumn{5}{c|}{ DNA-DNA hybridization (\%) with: } \\
\cline { 3 - 7 } & & $\mathbf{1}$ & $\mathbf{2}$ & $\mathbf{3}$ & $\mathbf{4}$ & $\mathbf{5}$ \\
\hline 1. A. gandavensis LMG 21285 & 65 & 100 & & & \\
2. A. gandavensis LMG 21286 & 65 & 98 & 100 & & \\
3. A. gandavensis LMG 21287 & 65 & 97 & 95 & 100 & \\
4. A. citreus LMG 16338 & 65 & 36 & 30 & 36 & 100 & \\
5. A. luteolus DSM 13067 & 66 & 49 & 41 & 50 & 36 & 100 \\
\end{tabular}

salicin, sorbitol, L-sorbose, starch, D-tagatose, trehalose, D-turanose, xylitol or D- or L-xylose. Variable in tests with $\mathrm{D}$-glucose, mannose and rhamnose. In addition to the reactions described in the text, strains are negative for pyrrolidonyl arylamidase (hydrolysis of L-pyroglutamic acid-AMC), $\beta$-glucuronidase, $N$-acetyl $\beta$-glucosaminidase, enzymic hydrolysis of L-valine-AMC, $4 \mathrm{MU}-\alpha$-D-glucoside, 4MU- $\beta$-D-glucuronide, L-isoleucine-AMC, $p$-nitrophenyl $\beta$-D-cellobioside and $p$-nitrophenyl $\alpha$-D-maltoside. Variable in tests for L-arginine-AMC, L-pyroglutamic acid-AMC, L-tryptophan-AMC， $4 \mathrm{MU}-N$-acetyl $\beta$-D-glucosaminide, 4MU-phosphate, $4 \mathrm{MU}-\beta$-D-glucuronide and gelatin liquefaction. Cell-wall peptidoglycan is based on the A3 $\alpha$ type
(L-Lys-L-Thr-L-Ala-L-Ala); major menaquinone is MK$9\left(\mathrm{H}_{2}\right)$. Predominant cellular fatty acid is anteiso- $\mathrm{C}_{15: 0}$; significant amounts of iso- $\mathrm{C}_{15: 0}$ and anteiso- $\mathrm{C}_{17: 0}$ are also present. DNA G $+\mathrm{C}$ content is $65 \mathrm{~mol} \%$.

The type strain is LMG $21285^{\mathrm{T}}$ ( = DSM $15046^{\mathrm{T}}$ ). Habitat is unknown. Isolated from mammary and uterine infections in cattle; its pathogenic role in these processes is uncertain.

\section{References}

Chun, J., Rhee, M.-S., Han, J.-I. \& Bae, K. S. (2001). Arthrobacter siderocapsulatus Dubinina and Zhdanov $1975^{\mathrm{AL}}$ is a later subjective 
synonym of Pseudomonas putida (Trevisan 1889) Migula $1895^{\mathrm{AL}}$. Int J Syst Evol Microbiol 51, 169-170.

Collins, M. D., Hoyles, L., Foster, G., Falsen, E. \& Weiss, N. (2002). Arthrobacter nasiphocae sp. nov., from the common seal (Phoca vitulina). Int J Syst Evol Microbiol 52, 569-571.

Conn, H. J. (1928). A type of bacteria abundant in productive soils, but apparently lacking in certain soils of low productivity. N Y Agric Exp Stn Geneva Bull 138, 3-26.

Ezaki, T., Hashimoto, Y. \& Yabuuchi, E. (1989). Fluorometric deoxyribonucleic acid-deoxyribonucleic acid hybridization in microdilution wells as an alternative to membrane filter hybridization in which radioisotopes are used to determine genetic relatedness among bacterial strains. Int J Syst Bacteriol 39, 224-229.

Funke, G., Hutson, R. A., Bernard, K. A., Pfyffer, G. E., Wauters, G. \& Collins, M. D. (1996). Isolation of Arthrobacter spp. from clinical specimens and description of Arthrobacter cumminsii sp. nov. and Arthrobacter woluwensis sp. nov. J Clin Microbiol 34, 2356-2363.

Goris, J., Suzuki, K., de Vos, P., Nakase, T. \& Kersters, K. (1998). Evaluation of a microplate DNA-DNA hybridization method compared with the initial renaturation method. Can J Microbiol 44, 1148-1153.

Groth, I., Schumann, P., Weiss, N., Martin, K. \& Rainey, F. A. (1996). Agrococcus jenensis gen. nov., sp. nov., a new genus of actinomycetes with diaminobutyric acid in the cell wall. Int J Syst Bacteriol 46, 234-239.

Hou, X.-G., Kawamura, Y., Sultana, F., Shu, S., Hirose, K., Goto, K. \& Ezaki, T. (1998). Description of Arthrobacter creatinolyticus sp. nov., isolated from human urine. Int J Syst Bacteriol 48, 423-429.
Jones, D. \& Keddie, R. M. (1992). The genus Arthrobacter. In The Prokaryotes, vol. 1, pp. 1283-1299. Edited by A. Balows, H. G. Trüper, M. Dworkin, W. Harder \& K.-H. Schleifer. New York: Springer.

Mesbah, M., Premachandran, U. \& Whitman, W. B. (1989). Precise measurement of the $\mathrm{G}+\mathrm{C}$ content of deoxyribonucleic acid by high-performance liquid chromatography. Int J Syst Bacteriol 39, 159-167.

Osorio, C. R., Barja, J. L., Hutson, R. A. \& Collins, M. D. (1999). Arthrobacter rhombi sp. nov., isolated from Greenland halibut (Reinhardtius hippoglossoides). Int J Syst Bacteriol 49, 1217-1220.

Pitcher, D. G., Saunders, N. A. \& Owen, R. J. (1989). Rapid extraction of bacterial genomic DNA with guanidium thiocyanate. Lett Appl Microbiol 8, 151-156.

Saitou, N. \& Nei, M. (1987). The neighbor-joining method: a new method for reconstructing phylogenetic trees. Mol Biol Evol 4, 406-425.

Skerman, V. B. D., McGowan, V. \& Sneath, P. H. A. (1980). Approved lists of bacterial names. Int J Syst Bacteriol 30, 225-420.

Vandamme, P., Vancanneyt, M., Pot, B. \& 10 other authors (1992). Polyphasic taxonomic study of the emended genus Arcobacter with Arcobacter butzleri comb. nov. and Arcobacter skirrowii sp. nov., an aerotolerant bacterium isolated from veterinary specimens. Int J Syst Bacteriol 42, 344-356.

Wauters, G., Charlier, J., Janssens, M. \& Delmée, M. (2000). Identification of Arthrobacter oxydans, Arthrobacter luteolus sp. nov., and Arthrobacter albus sp. nov., isolated from human clinical specimens. J Clin Microbiol 38, 2412-2415. 